\title{
Play Therapy on Separation Anxiety Children-A Case Report
}

\author{
Fu Rung Yang ${ }^{1}$ and I Jen Wang ${ }^{2 *}$ \\ ${ }^{1}$ Department of Educational, Taipei University, Taiwan \\ ${ }^{2}$ Department of Psychiatry, Taipei City Hospital, Ren-Ai Branch, Taiwan
}

Received: 眥 January 07, 2019; Published: 盋 January 16, 2019

*Corresponding author: I Jen Wang, Department of Psychiatry, Taipei City Hospital, Ren-Ai Branch, Taiwan

\begin{abstract}
The symptoms of regarding separation anxiety among children might last to adulthood. Those Children with separation anxiety have a tendency to come through relationship difficulty. In addition, they are inclined to have anxiety disorders, mental health problems so that they suffered from social impairment. Separation anxiety plays an important role in early-child developmental period; that is, separation anxiety should be valued by teachers and care givers. Therefore, the purpose of this essay wants to discuss on the causes of separation anxiety, do play therapy for a child with separation anxiety and shows how to deal with separation anxiety.
\end{abstract}

Keywords: Separation Anxiety; Play Therapy; Children

\section{Introduction}

Children like pulling and dragging with their moms outside the classrooms, in order to they don't want to leave their moms in preschool period. Children perform such behaviors lasting for only a few days while others might last for weeks. Children will reveal separation anxiety in different level when they enter a new environment, which will influence not only teachers but also parents. Separation anxiety is a developmentally appropriate reaction of distress to separation from the caregiver during infancy and toddler which is central to the child's psychological development [1,2]. Although most children can adequately learn to regulate their distress reaction to separation, but some children continue anxiety for a long period of time. When symptoms of separation anxiety continue, these behaviors can become highly problematic and debilitating [3]. Separation anxiety disorder is the most common anxiety classification below the age of 12 [4]. It is an antecedent of adult anxiety disorders and linked to depression in young adults $[5,6]$.

\section{Clinical Case}

A four-year-old girl lives with parents and two elder sisters. She lived with her grandparents in the other city before four years old. When she attended to kindergarten, a new environment induced her separation anxiety and non-nutritive sucking habit. Play therapy for her separation anxiety had 8 times. Agenda of 8 times showed as Table 1, at the same time, Table 2 showed the photos of child presentation in the play therapy.

Table 1: Play therapy agenda for 8 times.

\begin{tabular}{|c|c|}
\hline First time and second time & Agenda of Goals \\
\hline Third, fourth and fifth time & $\begin{array}{c}\text { Establishing friendly relationship with } \\
\text { the child } \\
\text { interest in the environment of the } \\
\text { kindergarten. Furthermore, trying to } \\
\text { reduce child's anxiety in fifth time. }\end{array}$ \\
\hline Sixth, seventh and eighth time & $\begin{array}{c}\text { Playing a role in reducing the child's } \\
\text { anxiety. }\end{array}$ \\
\hline
\end{tabular}

\section{Discussion}

Play therapy can enhance children in their verbal expression, i.e., to make their verbal expression more abundant and more diverse. The nonverbal behaviors become gradually relaxed, playful, as well as initiative. The girl explored outer world by playing toys, the girl improved her control and transform her inner emotion smoothly. The emotional and behavioral patterns of the girl became natural, pleasant, relaxed, considerate and active. In the end, her non-nutritive sucking habit disappeared. 
Table 2: Child presentation in the play therapy.

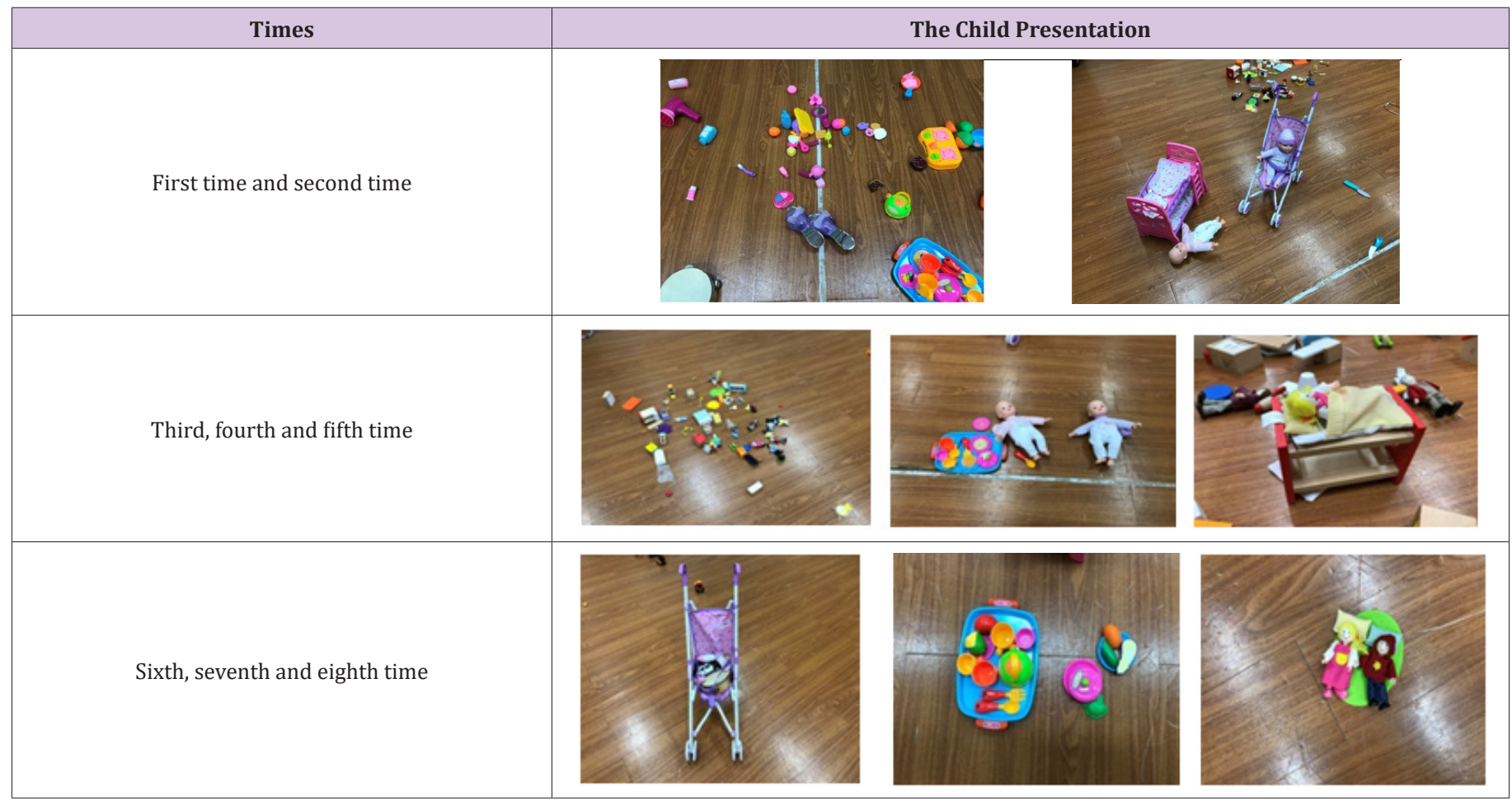

\section{Conclusion}

This article discussed play therapy for a four-year-old girl with separation anxiety. After the intervention, she alleviated her separation anxiety. As mentioned earlier, play therapy has positive effect in dealing with children with separation anxiety and related interpersonal relationship difficulties.

\section{References}

1. Bowlby J (1988) A secure base: Clinical applications of attachment theory. In Bowlby J (Eds.) London: Routledge, London.

2. Mahler MS (2000) The psychological birth of the human infant: Symbiosis and individuation. NY: Basic Books, New York, USA, pp. 308
3. Jurbergs N, Ledley DR (2005) Separation anxiety disorder. Pediatric Annals 34(2): 108-115.

4. Cartwright Hatton S, McNicol K, Doubleday E (2006) Anxiety in a neglected population: Prevalence of anxiety disorders in preadolescent children. Clinical Psychology Review 26(7): 817-833.

5. Hirshfeld Becker, Micco JA, Simoes NA, Henin A (2008) High risk studies and developmental antecedents of anxiety disorders. American Journal of Medical Genetics Part C: Seminarsin Medical Genetics 148(2): 99-117.

6. Kossowsky J, Pfaltz MC, Schneider S, Taeymans J, Locher C, et al. (2013) The separation anxiety hypothesis of panic disorder revisited: A metaanalysis. American Journal of Psychiatry 170(7): 768-781.

\section{ISSN: 2574-1241}

DOI: $10.26717 /$ BJSTR.2019.13.002357

Jen Wang. Biomed J Sci \& Tech Res

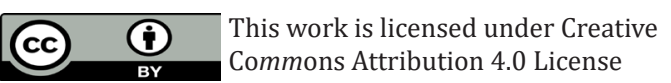

Submission Link: https://biomedres.us/submit-manuscript.php

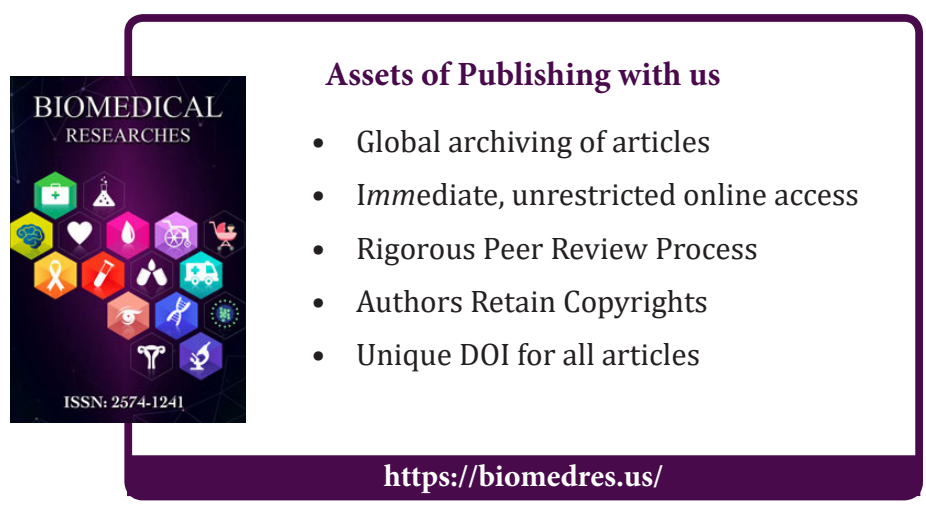

